\title{
Changing Forests and Forest Management Policy in Relation to Dealing with Forest Diseases
}

\author{
Robert L. Anderson
}

Former Director, Forest Health Protection (Retired), U.S. Department of Agriculture Forest Service, Southern Region, Atlanta, GA 30367. Accepted for publication 7 March 2003.

\begin{abstract}
Anderson, R. L. 2003. Changing forests and forest management policy in relation to dealing with forest diseases. Phytopathology 93:1041-1043.

The forest landscape of the United States has changed over time, as has public concern for the trees, water, and wildlife. Early in the history of the United States, forests were viewed as an encumbrance and an inexhaustible resource, used to meet the needs of a growing nation. Around 1900, it became clear that old approaches were not sustainable and forest pathology saw its beginning. Annual lumber production increased from 5.4 billion to 44.5 billion board feet. Forest pathologists were called upon to help manage forests for a variety of products, with a focus on decays of wood and wood products. Projection of timber famine stirred public concern, and a number of laws were enacted to deal with the issue. Pathologists were called upon to deal with many of the issues

associated with intensive management, and new pests such as chestnut blight and white pine blister rust demanded attention. Then pathologists were called upon to help manage for multiple benefits, and the issues became more complex. Pests such as mistletoes, root diseases, rusts, nursery pests, and urban pests presented new challenges. Concepts such as landscape level assessments, ecosystem management, and multipleuse led to the management of forests to provide for a complex variety of needs. Management objectives vary across the landscape, and pathologists find themselves working with managers who want to maximize fiber production, those that manage areas set aside for special purposes, and all combinations in between. Issues such as acceptable levels of pests, nonnative invasive species, landowner values, visual and watershed quality, and best management practices must be considered in an ever-changing landscape.
\end{abstract}

The goal of this paper is to present a historical perspective on how forests and management policies have changed over time in relation to forest diseases. This paper presents the career experience of the author, reinforced and supplemented by the literature sources. The sources provided specific information on the forest resource $(1,5,13,14)$, forest pathology $(2)$, forest resource history $(3,4,7,8,12,15)$, forest management (6), conservation issues (9), and National Forest Systems $(10,11)$.

The forest landscape of the United States has changed over time, as has public concern for the trees, water, and wildlife. The conservation movement of the early 20th century and the policy changes that resulted from that movement have been leading factors affecting the forests of today. The original forest covered about 1 billion acres and was perceived as a universal forest that started at the Atlantic and thickened and enlarged to the heart of the country. Today there are about 740 million acres of forest, about $70 \%$ of the original forest. East of the Mississippi, hardwood and conifer forests covered New England, pines covered the southern coastal plain and Piedmont, varied hardwood forests extended from the Appalachians through the Ohio Valley and central Midwest, and extensive pine and oak woodlands grew further to the Midwest on the prairie fringe. West of the Mississippi, upland forests gradually gave way to riparian forests in the prairies and deserts, in turn giving way to extensive coniferous forests in the mountainous areas of the West and along the Pacific

Corresponding author: R. L. Anderson; E-mail address: RLA89@hotmail.com

Publication no. P-2003-0602-030

This article is in the public domain and not copyrightable. It may be freely reprinted with customary crediting of the source. The American Phytopathological Society, 2003.
Coast. The most magnificent western forests grew along the coast in the far West. Diseases, such as decay and root rots, commonly associated with old growth trees and repeated fires, were common throughout much of the forested landscape.

Forests in the East and West were not pristine at the time of European settlement. They had been strongly influenced by Native Americans, and the use of fire as a management tool was a common event. The European settlement of the United States brought a vast increase in the impact of humans on the landscape. The early colonist viewed the seemingly endless forest as a mixed blessing. The forest was a source of fuel and building materials. It yielded food but was home to predators of their livestock. It also provided cover for sometimes-hostile Native Americans, but more important it occupied prime farmland. Colonial use of forest products was extensive. It is estimated that at one time there were over 3.2 million miles of wooden fence in the United States. Wood products were also a source of industry. Almost every American Colony had a number of iron making furnaces. These required a total of 20,000 to 30,000 acres of forest to continue operating. The land clearing, grazing of the woods, repeated fires, and high grading resulted in trees of poor quality with extensive decay and root diseases.

In the late 1800s and early 1900s, annual lumber production increased from about 5.4 to 44.5 billion board feet. Farmers often cut, piled, and burned trees and brush to convert forests to crop land. Wildfire commonly consumed 20 to 50 million acres annually. There were 80 million acres of cutover land that was idle or lacked desirable trees, cut exceeded growth, and there was little provision for reforestation. Yet massive clearing of land for agriculture continued. Decay, root diseases, and canker diseases were common in the regrowth. Erosion and compaction from poor farming practices influenced diseases that would later follow, 
such as oak decline and littleleaf disease. Plant pathology had its beginning about this time; DeBary demonstrated that fungi can cause disease. Robert Hartig is recognized as the first person to concern himself with tree diseases; he demonstrated the relationship between decay in the trees and the fungi causing them.

At this same time, people were predicting an impending national famine of wood. People saw the loss of $80 \%$ of the forest in certain geographic areas. Fear of a wood famine and other issues started the first conservation movement. In 1875, the American Forestry Association was formed, and in 1892, the Sierra Club was started. This founding reflected the public's concerns for forests of the United States.

In 1891, Congress authorized the President to designate forest reserves out of public domain land but made no provision for their management. The reserves grew to 40 million acres by 1897 when the Organic Act was enacted to preserve and protect the forests and to secure favorable conditions for water flow. By 1915, the national forests of the West had been established in the form they retain today. By 1925, land had been purchased in the East to establish a number of national forests.

In response to the growing need for disease management, the Office of Forest Pathology was formed in 1909. Scientists in this office gained considerable exposure where they worked on traditional diseases such as heart rot and other diseases on national forest lands, but their work was expanding to nurseries and plantation management. Chestnut blight had just been discovered (1904) and its impact was being felt. By the late 1930s, the blight had spread throughout the range of American chestnut and had killed most of the large trees. White pine blister rust, caused by Cronartium ribicola, was also introduced in the early 1900s, and this disease would occupy a considerable amount of the office's resources. Ribes eradication employed thousands of people across the United States. The Plant Quarantine Act of 1912 was enacted to deal with nonnative species and to minimize the introduction of other pests. Policies that emerged to address the issues in the 1930s emphasized protecting the forest from wildfire; managing wildlife; managing forests to protect them from wildfire, insects, and diseases; acquiring scientific knowledge about the management of forests; encouraging management on private land; and acquiring and managing public lands. These policies resulted in the exploration of management strategies to minimize losses from forest diseases with an emphasis on decays. While this was happening, massive farm abandonment was occurring during the Great Depression of the 1930s. This abandonment strongly influences many of the decline diseases of today.

The U.S. Department of Agriculture (USDA) Forest Service created its research branch in 1915. This grew further with the passage of the McSweeny-McNary Act in 1928. The act expanded research and authorized regional research stations and a national inventory program. Forest industry also started research on insect and disease control. In 1911, Congress passed the Weeks Act, which authorized federal matching funds for state fire control agencies. In 1924, the Clarke-McNary Act augmented cooperative federal and state fire suppression efforts as well as existing funding under the Weeks Act. It authorized a major study of forestland taxation and assistance to tree nurseries. The Universities responded by producing foresters to meet the challenge of increased forest management. In 1939 they graduated 1,200 foresters.

It was at this time that the state forestry agencies started to consider the impacts and management of forest pests. In some states, the state forestry programs preceded the federal actions. California and New York had formed forestry commissions as early as 1885 . In the 1940s, with the passage of various state forestry practices, the USDA Forest Service campaigned for federal regulation and the states became the regulators of forestry practices. Managing forests to minimize forest diseases was considered in most programs, but fire control was the major emphasis area.
At the end of World War II, demand for housing increased dramatically and the nation looked to the national forests to meet the demand. National forest timber sales increase from 3 billion board feet in the late 1940s to about 12 billion board feet after the 1950s. After World War II, the increased price for wood created powerful incentives to use wood substitutes. New technology emerged, and trees left behind were harvested. The decay-riddled, poor-quality trees could now be removed, and cash incentives enabled managers to start serious management of their forests, which included disease control. Tax codes encouraged owners to harvest timber to reduce their tax burden. By 1960 many states had changed their codes to a timberland basis, and in 1964 the federal tax system revised timber harvest income tax laws and applied a capital gain tax. Tree planting increased dramatically after 1950, rising from about 7,000 acres per year in 1945 to 1.2 million acres in the 1980s. This intensive management brought new challenges for the forest pathologist. A long list of forest nursery diseases emerged as significant to managers, along with an equally long list of significant regeneration diseases. Pests such as fusiform rust gained new prominence as a result of the intensive management. Exotics such as chestnut blight and white pine blister rust were demanding increased attention and resources. Beginning in the 1950s, pathologists were in high demand to deal with these new issues.

In the late 1950s, a fundamental change was occurring in forest utilization. There was a substantial increase in demand for other national forest uses and values. The Multiple Use-Sustained Yield Act of 1960 required that national forests be managed for a variety of uses and values, including outdoor recreation, wildlife, timber, grazing, and watershed protection. It specifically provided authority to develop and administer the renewable resources of the national forests for multiple use and sustained yield of the several products and services. This shift from timber production to managing for multiple resources brought new challenges to forest pathologists. Pathologists became heavily involved in managing forest recreation areas and issues such as hazard tree management gained new prominence. The Wilderness Act of 1964 provided for the preservation of significant areas of national forest land in their natural condition. This also presented new challenges for forest pathologist on how to manage areas so pests did not affect the natural condition. The Wilderness Society, formed in 1935, began to exercise its clout in setting forestry priorities. In 1974 the Renewable Resources Planning Act required the USDA Forest Service to carry out periodic assessments of the national long-term policy. It directed the secretary of agriculture to prepare periodic assessments of the status of the nation's forest resources. Section three of the Act directed the secretary to make and keep current a comprehensive survey and analysis of the present and prospective conditions of the renewable resources of the forestlands of the United States. Section seven authorized the secretary to utilize the assessments, resource surveys, and the program prepared pursuant to this act to assist states and other organizations in proposing planning for the protection, use, and management of renewable resources on nonfederal land. In 1976, the National Forest Management Act provided detailed guidelines for national forest land management public participation in the decision making process. This Act made it clear that the congressional intent was to provide detailed guidelines for managing the national forests.

It was about this time (mid-1970s) that the modern environmental movement took form. Environmental quality became a high priority. Litigation became a tool of public organizations to influence management policy. The Forest and Rangeland Renewable Resources Planning Act of 1974 and the Land and Resource Management Planning Regulations of the USDA Forest Service mandated public inclusion in land management planning. These programs established key principles on which regional and forest planning for the national forests would be based. It recognized that national forests are ecosystems and their management for 
goods and services requires an awareness of the interrelationships of their component parts. It set forth minimum requirements to guide forest plan development and implementation for the $\mathrm{Na}$ tional Forest System including resource protection requirements to address hazard and damage from pest organisms, protect diversity of plant and animal communities, and protect fish and wildlife habitat. Earth Day opened the door for the National Environmental Policy Act (1979), a federal watershed in managing lands and resources. As the environmental movement grew and the nation demonstrated it could meet the timber needs from state and private lands, more of the national forest land base has been set aside for recreation, wilderness, unsuitable for timber, and similar designations under which timber removal was prohibited.

In 1978 the Cooperative Forestry Assistance Act was passed. It provided authority to protect forest health directly on National Forest System lands and, in cooperation with others, on other forested lands in the United States. Specifically, the Act provided authority to conduct surveys to detect and appraise insect infestations, disease conditions, and man-made stresses affecting trees. It also authorized establishing a monitoring system throughout the forests of the United States to determine detrimental changes or improvements that occur over time, and to report annually concerning such surveys and monitoring. Additionally, it provided authority to promote the implementation of silvicultural or management techniques to improve the health of the forests of the United States, to provide technical and related assistance on techniques to maintain healthy forests, and to take any other actions the secretary of agriculture determined to be necessary to accomplish the objectives and purposes described in the Act. The 1978 Forest and Rangeland Renewable Resources Research Act as amended in 1988 directed the Forest Service to establish a 10-year program to better understand the cause of changes in the health and productivity of domestic forest ecosystems. It directed the forest service to increase the frequency of forest inventories in matters that relate to atmospheric pollution and conduct such surveys as are necessary to monitor long-term trends in the health and productivity of domestic forest ecosystems.

So where are we now? The National Forest System is managed to maintain healthy watersheds. There is little cutting of trees done on the national forests, the forests are aging, risk and hazard for forest diseases is increasing at an alarming rate, and a number of nonnative invasive species are positioned to have major impacts on the ecosystems. The national forests are managed for a variety of nontimber values such as recreation and wildlife. This emphasis brings new challenges to the forest pathologists. Other federal ownerships have a variety of priorities, from fairly intensive management of the forest resource to almost no management. State lands also have a variety of management strategies, but there seems to be a trend of less timber management toward management for other values. The industry picture is changing also. Mergers and focus on profit have created a situation in which intensive management is viewed as the norm but the long-term commitment to the land and reforestation varies with the company and the current managers. These new management strategies bring new and increasing problems and issues for the pathologist. For example, clonal plant material seems to be an open invitation for diseases. The nonindustrial private landowner scene is also changing. Landowner values are rapidly changing where forest management is not a priority. Fragmentation of the landscape with the land ownership getting smaller every year brings new management challenges. The urban interface brings new challenges, many of which are yet to be defined and developed.

Looking back, attitudes about the nation's forests have changed profoundly. Initially the forests were viewed as an encumbrance.
Then there was a great demand for forest products to build homes. This was followed by a fear that the timber resource was not sustainable, and then a realization that the forests could be managed. Following close behind was a need for multiple resources, and now the need for recreation and personal renewal have followed. As we look back, the timber famine never arrived, and most species whose extinction was predicted have recovered. The predictions were in many cases a call for action. It was public opinion that actually shaped the changes. The policies that were debated and finally implemented basically reflect the will of the people. History has shown that the policies, coupled with the resiliency of the natural resource, have dealt with many of the issues raised. Now as we stand looking into the future we see new issues and new public opinions influencing new policies to be enacted. Forest fragmentation, growing urbanization, mobility of Americans, nonnative invasive species, demand for increased recreation, ecosystem management, land manager values, land user values, litigation, protection of old growth timber, endangered species, loss of wetlands, pesticides, and air pollution are just some of the issues influencing the current debate over appropriate management of America's forest resource. These issues and many we have not thought of will shape the future of forest pathology. We will need to build on successes of the past and respond to the new challenges. New strategies are already being developed to respond to many of these issues. As the public pressure builds, the policies will follow, and forest pathology must be prepared to work within the policies to provide solutions to problems continually increasing in complexity. How effective forest pathologists will be in helping maintain and restore the ecosystems of the United States remains to be seen.

\section{LITERATURE CITED}

1. American Forestry Association. 1990. Natural Resources for the 21st Century. Island Press, Washington, DC.

2. Cambell, C. L., Peterson, P., and Griffith, C. 1999. The Formative Years of Plant Pathology in the United States. The American Phytopathological Society, St. Paul, MN.

3. Clawson, M. 1979. Forests in the long sweep of American history. Science 204:1168-1174.

4. Cronon, W. 1985. Changes in the Land: Indians, Colonists, and the Ecology of New England. Hill and Wang, New York.

5. Cronon, W. 1991. Nature's Metropolis: Chicago and the Great West. W. W. Norton and Company, New York.

6. Fedkiw, J. 1989. The evolving use and management of the nation's forests, grasslands, croplands, and related resources. U.S. Dep. Agric. For. Serv. Gen. Tech. Rep. RM-175.

7. Frederick, K. D., and Sedjo, R. A. (eds.) 1991. America's Renewable Resources: Historical Trends and Current Challenges. Resources for the Future. Washington, DC.

8. Perlin, J. 1989. A Forest Journey: The Role of Wood in the Development of Civilization. W. W. Norton and Company, New York.

9. Reiger, J. F. 1986. American Sportsmen and the Origins of Conservation. University Press, Norman, OK.

10. Shands, W. E. 1992. The lands nobody wanted: The legacy of the eastern national forests. In: The Origins of the National Forests. H. K. Steen, ed. Forest History Society, Durham, NC.

11. Steen, H. K. 1976. The U.S. Forest Service: A History. University of Washington Press, Seattle.

12. Thompson, D. Q., and Smith, R. 1970. The forest primeval in the Northeast-A great myth? Proc. Annu. Tall Timbers Fires Ecol. Conf. 10:255-265.

13. U.S. Department of Agriculture. 1982. Analysis of the timber situation in the United States, 1952-2030. U.S. Dep. Agric. For. Serv. For. Resour. Rep. No. 23.

14. U.S. Department of Agriculture. 1989. Forest statistics of the United States, 1987. U.S. Dep. Agric. For. Serv. Gen. Resour. Bull. PNW-RB-168.

15. Whitney, G. G., and Davis, W. C. 1986. From primitive woods to cultivated woodlots: Thoreau and the forest history of Concord, Massachusetts. J. For. History 30:70-81. 